\title{
Working with Nonprofit Organizations in Community Settings: Governance, Florida Statutes and Legislation
}

Elizabeth B. Bolton and Anna Guest-Jelley

\section{Nonprofit Organizations and Legislation}

As nonprofit organizations continue to grow in number and importance, legislation is developed governing their action. This legislation is designed to ensure the public's trust in nonprofits, and to help nonprofits structure their organizations.

\section{Florida Statutes}

Requirements for nonprofit boards of directors are outlined in the Florida Statutes Chapter 617, the Florida Not for Profit Corporation Act. It is amended every year by the legislature, although in most years few changes are made to the document. Nevertheless, it is important for boards to keep these statutes in mind as they develop their roles and responsibilities and as they carry out their duties. The following, adapted from the 2008 Florida Statutes Chapter 617, is intended only to provide general guidelines for board members.

\section{Requirement for and duties of board of directors}

All corporate powers must be managed under the direction of its board of directors.

\section{Qualifications of directors}

1. Directors must be 18 years of age or older and not necessarily residents of this state.

2. If eligibility to serve as a member of the board of directors of a property owners' association is restricted to membership and to ownership, a grantor of a trust or a beneficiary who owns and occupies property is considered a member of the association and is therefore eligible to serve as a director.

1. This publication is FCS9245, one of a series of the Department of Family, Youth and Community Sciences, Florida Cooperative Extension Service, Institute of Food and Agricultural Sciences, University of Florida. Adapted from Chapter 617, 2008 Florida Statutes. First published: June 2009. Please visit the EDIS Web site at http://edis.ifas.ufl.edu. Reviewed June 2012.

2. Elizabeth B. Bolton, Ph.D., professor of Community Development, Department of Family, Youth and Community Sciences; Florida Cooperative Extension Service; Institute of Food and Agricultural Sciences; University of Florida; Gainesville, Florida 32611 - 0310; and, Anna Guest-Jelley, MFYCS, MA, director of Violence Prevention Program, Peaceful Paths Domestic Abuse Network, also of Gainesville, FL. 


\section{Number of directors}

1. A board of directors must consist of three or more individuals.

2. The number of directors may be increased or decreased from time to time, but must never have fewer than three directors.

3. Directors shall be elected or appointed as specified in the organization's articles of incorporation or its bylaws.

\section{Staggered terms for directors}

Directors may be divided into classes and the terms of office need not be uniform.

\section{Resignation of directors}

1. A director may resign at any time by delivering written notice.

2. A resignation is effective when the notice is delivered, or at a later effective date. If a resignation is made effective at a later date, the successor cannot take office until the effective date.

\section{Removal of directors}

A director may be removed from office by following these procedures:

1. Any member of the board of directors may be removed from office with or without cause by majority vote of the governing membership.

2. The notice of a meeting of the members to recall a member or members must include the names of the proposed directors to be removed.

3. A proposed removal of a director at a meeting shall require a separate vote for each board member.

4. If removal is effected at a meeting, any vacancies created shall be filled by the members at the same meeting.

5. Any director who is removed from the board will not be eligible to stand for reelection until the next annual meeting of the members.

6. Any director removed from office shall turn over to the board of directors within 72 hours any and all records of the corporation in his or her possession.

7. If a director who is removed does not relinquish his or her office or turn over records as required, a court order can be issued to facilitate compliance with these statutes.

\section{Vacancy on board}

1. Any vacancy occurring on the board of directors may be filled by the affirmative vote of the majority of the remaining directors.

2. A director elected or appointed to fill a vacancy shall be elected or appointed for the remainder of the term of the office.

3. A vacancy that will occur at a specific later date may be filled before the vacancy occurs. However, the new director may not take office until the vacancy occurs.

\section{Compensation of directors}

Unless the articles of incorporation or the bylaws provide otherwise, the board of directors may fix the compensation of directors. 


\section{Meetings}

1. The board of directors may hold regular or special meetings in or out of this state.

2. A majority of the directors present may adjourn any meeting of the board of directors to another time and place.

3. Meetings of the board of directors may be called by the chair of the board or by the president unless the articles of incorporation or the bylaws state otherwise.

4. The board of directors may permit any or all directors to participate in a regular or special meeting conducted through the use of teleconferencing and be considered as present in person.

\section{Action by directors without a meeting}

1. Action taken by boards of directors may be taken without a meeting if taken by all members of the board and if one or more written consents describing the action taken are signed by each director.

2. Action taken without a meeting is effective when the last director signs the consent.

3. A signed consent has the effect of a meeting vote and may be described as such in any document.

\section{Notice of meetings}

1. Regular meetings of the board of directors may be held without notice of the date, time, place, or purpose of the meeting.

2. A special meeting of the board of directors must be preceded by at least 2 days' notice of the date, time, and place of the meeting.

\section{Waiver of notice}

Notice of a meeting of the board of directors need not be given to any director who signs a waiver of notice either before or after the meeting.

\section{Quorum and voting}

1. A quorum of a board of directors consists of a majority of the number of directors.

2. A quorum of a board of directors must consist of no less than one-third of the prescribed number of directors determined under the articles of incorporation or the bylaws.

3. If a quorum is present when a vote is taken, the vote of a majority of directors present is considered affirmative.

4. A director of a corporation who is present at a board or committee meeting when corporate action is taken is deemed to have assented to the action taken unless:

a. The director objects, at the beginning of the meeting to holding the meeting or transacting specified affairs at the meeting; or,

b. The director votes against or abstains from the action taken.

\section{Committees}

1. The board of directors may designate from among its members an executive committee and one or more other committees, each of which shall have and may exercise all the authority of the board of directors with the following exceptions: 
a. Approve or recommend to members actions or proposals required by this act to be approved by members

b. Fill vacancies on the board of directors or any committee

c. Adopt, amend, or repeal the bylaws

2. Meetings, notice, and waiver of notice, and quorum and voting requirements of the board of directors, apply to committees and their members as well.

3. Each committee must have two or more members who serve at the pleasure of the board of directors. The board may designate one or more directors as alternate members of any such committee.

4. The designation of any committee shall not alone constitute compliance by any member of the board of directors who is not a member of the committee in question with his or her responsibility to act in good faith with the best interests of the corporation.

\section{General standards for directors}

1. A director shall discharge his or her duties as a director or member of a committee:

a. In good faith;

b. With the care an ordinarily prudent person in a like position would exercise under similar circumstances; and,

c. In a manner he or she reasonably believes to be in the best interests of the corporation.

2. In discharging his or her duties, a director may rely on information prepared or presented by:

a. One or more officers or employees of the corporation;

b. Legal counsel, public accountants, or other persons with professional or expert competence; or,

c. A committee of the board of directors of which he or she is not a member if the director reasonably believes the committee merits confidence.

3. A director is not acting in good faith if he or she has knowledge concerning the matter in question that makes reliance unwarranted.

4. A director is not liable for any action taken as a director, or any failure to take any action, if he or she performed the duties of his or her office in compliance with this section.

\section{Indemnification and liability of officers, directors, employees, and agents}

Any reference to directors or shareholders includes the directors, managers, or trustees of a corporation, organized under this act or a rural electric cooperative. The term director does not apply to property associations or a timeshare managing entity. See Officers and directors of certain corporations and associations not for profit; immunity from civil liability later in this document.

\section{Director conflicts of interest}

1. No contract or other transaction between a corporation and one or more of its directors financially interested shall be void, due to presence at the meeting of the board or committee which authorizes, approves, or ratifies such contract or transaction if:

a. The fact of such relationship or interest is disclosed or known to the board of directors or committee;

b. The fact of such relationship or interest is disclosed or known to the members entitled to vote;

c. The contract or transaction is fair and reasonable.

2. Interested directors may be counted in determining the presence of a quorum. 


\section{Loans to directors or officers}

Loans may not be made by a corporation to its directors or officers, or to any other corporation, except a loan by one corporation which is exempt from federal income taxation under to another corporation which is exempt from federal income taxation.

\section{Officers and directors of certain corporations and associations not for profit; immunity from civil liability}

1. An officer or director of a nonprofit organization is not personally liable for monetary damages to any person unless:

a. The officer or director failed to perform his or her duties as an officer or director; and

b. The officer's or director's failure to perform, his or her duties constitutes:

1. A violation of the criminal law;

2. A transaction from which the officer or director derived an improper personal benefit;

3. Recklessness or an act or omission which was committed in bad faith or with malicious purpose.

2. For the purposes of this section, the term:

a. "Recklessness" means acting in conscious disregard of a risk:

1. Known, or so obvious that it should have been known; and

2. Known to the officer or director, to be so great as to make it highly probable that harm would follow from such action or omission.

b. "Director" means a person who serves as a director, trustee, or member of the governing board of an organization.

c. "Officer" means a person who serves as an officer without compensation except reimbursement for actual expenses incurred.

\section{Other relevant statutes}

There are other relevant statutes dealing with the Director's of nonprofit boards and these deal with liability, conflict of interest and contracting with the board, to name a few. It is recommended that you obtain a copy of Chapter 617 and review these statutes. This review is intended only to help you understand the importance of the governance function and that Boards of Directors represent a legal entity-it should not be used nor relied upon as a substitute for professional, legal advice.

\section{References}

Florida Not for Profit Corporation Act, Florida Statutes § 617.01011-617.2103 (2008). [Online] Available at http://www.leg.state.fl.us/Statutes/. 